\title{
Yöntem Olarak Yaratıcı Drama Kullanımının İlkokul 4. Sınıf Sosyal Bilgiler Programındaki Değerlere Etkisi
}

\author{
In The Social Studies Curriculum of Primary Schools: The Effect on the Values \\ of $4^{\text {th }}$ Grade Students of Using Creative Drama as a Method
}

\section{Ebru ERDEM ZENGIN* EIvan YALÇINKAYA**}

\begin{abstract}
$\ddot{O} z$ : Araştırma, yaratıcı dramanın yöntem olarak kullanılmasının, ilkokul dördüncü sınıf sosyal bilgiler programındaki değerlere etkisini belirlemeye yöneliktir. Yaratıcı drama yöntemi kullanılarak sosyal bilgiler 4. sınıf programında yer alan "hoşgörü", "duygu ve düşüncelere saygl" değerlerinin öğretimi gerçekleştirilmeye çalışılmıştır. Bu çalışmada ön test-son test kontrol gruplu desen kullanılmış olup, deneysel çalışmayla elde edilen bilgiler nitel verilerle desteklenmiştir. Araştırmada biri deney, diğeri kontrol grubu olmak üzere yansız atama yöntemiyle oluşturulmuş iki grup bulunmaktadır. Her iki gruba deney öncesi ve deney sonrası "hoşgörü tutum ölçeğì" uygulanmıştır. Çalışmalarda, araştırmacı tarafindan geliştirilen ve uzman görüşü alınan, 4 haftalık yaratıcı drama programı uygulanmıştır. Çalışma, 20122013 eğitim-öğretim y1lı bahar yarıyılında bir devlet ilkokulunda okuyan 22 öğrenci ile yürütülmüştür. Araştırmanın veri toplama sürecinde yapılan odak grup görüşmeleri video kamera ile kayıt altına alınmıştır. Öğrencilerin her ders sonrasında yazdığı günlükler incelenmiştir. Tutum ölçeğinden elde edilen veriler SPSS 15.0 paket programı ile analiz edilmiştir. Deney ve kontrol grubunda yer alan öğrencilerin uygulama öncesi tutumları arasında anlamlı farklılık bulunamamıştır. Kontrol ve deney grubundaki öğrencilerin tutumlarının birbirine yakın seviyede olduğu görülmektedir. Uygulama sonrasında ise yaratıcı drama ağılıklı yürütülen etkinliklerin öğrencilerin tutumlarını artırmada yapılandırmacı yaklaşıma göre daha etkili olduğu görülmüştür. Yaratıcı drama etkinliklerine katılan öğrencilerin hoşgörü ile duygu ve düşüncelere saygı değerlerini ve bu değerlerle ilgili davranışları öğrendikleri belirlenmiştir.
\end{abstract}

Anahtar sözcükler: Sosyal Bilgiler, Yaratıcı Drama, Değer Öğretimi, Hoşgörü, Duygu ve Düşüncelere Saygı

Abstract: This research aimed to determine the effects of using the creative drama technique in teaching social values to $4^{\text {th }}$ grade students. In this study the values of "tolerance" and "respect for beliefs and ideas" were targeted to be taught through applying the creative drama method. Pre-test and post-test research was conducted using a likert type scale on both the treatment and control groups. The method was employed over a 4 week period using a creative drama program that has been created by the researcher based upon the feedback from other researchers. The study was conducted in a Turkish primary school (n: 22) the focus group was recorded while taking the treatment and they were asked to write their journals at the end of each lesson. The data was analyzed through statistical computer programs. The pre-test results of both treatment and control groups showed the students attitudes were similar at the beginning. However, analysis of the post test results showed a significant difference between the scores of these groups at the end of the experiment, with students in the treatment group more successful in learning how to be tolerant and in having respect for opposing ideas and beliefs. The results also provided evidence for the effects of the creative drama technique in teaching social values when compared to the constructivist approach.

Keywords: Social Studies, Creative Drama, Teaching Values, Tolerance, Respect for Beliefs and Ideas

\footnotetext{
* Öğretmen, Milli Eğitim Bakanlığı, Niğde. ebruerdem-38@hotmail.com

** Doç. Dr., Ömer Halisdemir Üniversitesi, Eğitim Fakültesi, Sosyal Bilimler ve Türkçe Eğitimi Bölümü, Sosyal Bilgiler Öğretmenliği ABD, Niğde. eyalcinkaya@ohu.edu.tr

Bu makale Doç. Dr. Elvan YALÇINKAYA danışmanlığında Ebru ERDEM ZENGİN tarafindan hazırlanan aynı başlıktaki yüksek lisans tezinden üretilmiştir.
} 
Giriş

Dünyada gelişmiş ve gelişmekte olan bütün ülkeler eğitime ve eğitim programlarının yenileşme hareketlerine önem vermektedirler. Günümüzde gelişmiş dünya ülkelerinin eğitim programlarına bakıldığında, bu ülkelerin eğitim programlarının şekillenmesinde en fazla etkili olan anlayış "yapılandırmacılıktır". Ülkemizde, yapılandırmacılık esas alınarak hazırlanan sosyal bilgiler öğretim programı 2005 yılından itibaren uygulanmaya başlanmıştır. Yapılandırmacı eğitimin en önemli özellikleri öğrencinin aktif olması, bilgiyi yapılandırmasına, oluşturmasına ve geliştirmesine imkân sağlamasıdır. Değişen eğitim anlayışıyla birlikte Sosyal Bilgiler Öğretim Programında çeşitli değişiklikler yapılmış, öğrenme alanları belirlenmiş, bu öğrenme alanları için her sınıf düzeyinde üniteler oluşturulmuş ve kazanımlarla, kavram, bilgi, beceri ve değerlere yer verilmiştir. Bu öğretim programında her öğrenme alanı için öğrenciye doğrudan kazandırılması gereken değerler belirlenmiştir. Bu araştırmada "duygu ve düşüncelere saygı" ve "hoşgörü" değerleri, yaratıcı drama yöntemi kullanılarak öğrencilere kazandırılmaya çalışılmıştır ve yaratıcı drama yönteminin bu değerlere etkisi araştırılmıştır.

Sosyal bilgiler öğretiminde temel amaç, günümüz dünyasında çağdaş toplumlar seviyesine ulaşmak için bireylerin karşılaştıkları sorunları çözebilmeleri ve yaşadıkları kültürde çok yönlü eğitim ile ideal vatandaş düzeyine ulaşmalarını sağlamaktır. $\mathrm{Bu}$ anlamda sosyal bilgiler programının temel çıktısı, ahlaki değer ve etik sistemine dayalı olan, kararlar alabilen, adalete sayg1 duyan, güzeli takdir eden ve düşünen bireyler yetiştirmektir (Baydar 2009,15). Sosyal bilgilerin amacı doğrultusunda 2005 yılında yapılandırmacı eğitim anlayışı uygulanmaya başlanmıştır. Yapılandırmacı eğitimin en önemli özelliği, öğrencinin aktif olmasına, bilgiyi yapılandırmasına, oluşturmasına ve geliştirmesine firsat vermesidir. Geleneksel yöntemlerin dışında olan bu yaklaşımın özünde öğrenciye yardımcı olma ve rehberlik etme vardır. Geleneksel eğitim yöntemleriyle öğrencilerin bilişsel, duyuşsal ve devinişsel öğrenmelerini aktif katılımla gerçekleştirmek mümkün olmamaktadır. Eğitim sistemimiz öğrenciyi merkeze almaktadır. Yaratıcı drama, öğrenme-öğretme sürecinde öğrencinin sürece katılımını sağlayan, yaparak- yaşayarak öğrenmesine olanak veren yöntemlerden biri olarak görülmektedir (Akfirat 2004, 69-70). Sosyal bilgiler öğretiminde soru-cevap, anlatım, tartışma, gezi-gözlem, beyin firtınası, örnek olay, demonstrasyon (gösterip yaptırma), problem çözme ve yaratıcı drama gibi çeşitli öğretim yöntemleri kullanılmaktadır. Bu yöntemlerden yaratıcı drama yöntemi öğrenme ortamını eğlenceli hale getirerek öğrencilerin derse olan güdülerini ve dikkatlerini artırır. Bu nedenle sosyal bilgiler dersi için oldukça etkili ve önemlidir (Sever, Yalçınkaya \& Mazman 2009, 155).

\section{Sosyal Bilgiler}

Sosyal Bilgiler kavramının ortaya çıktığı günden beri tanımı ve içeriği noktasında çeşitli görüşler öne sürülmüş ve sosyal bilgiler konusunda farklı tanımlar ortaya konulmuştur. Bunun en önemli nedeni, sosyal bilgilerin sosyal bilimlerin içinde yer alan farklı tanımlara sahip birçok disiplinden oluşmasıdır. Sosyal bilgiler, "insan ve onun fiziki ve sosyal çevresiyle geçmişte, günümüzde etkileşimini ele alan, sosyal bilimlerdeki çeşitli disiplinlerin muhtevalarını, metotlarını, disiplinler veya disiplinlerarası bir yaklaşım ile sı sı tabiat bilimleri ve sanat ile zenginleştirerek adapte eden bir hüviyettedir" (Köken 2002, 111). Kıyıc1 (2002, 111), sosyal bilgileri, "Bireyin sosyal ve fiziki çevresiyle olan etkileşimini geçmişten geleceğe kadar uzanan zaman süreci içerisinde inceleyen ve bireyin topluma uyumunu sağlayıp, onun sosyal bir varlık olarak toplum içerisinde yer almasını konu edinen bir çalışma alanı" olarak tanımlamıştır. Köstüklü'ye $(1998,11)$ göre ise sosyal bilgiler, "öğretim amactyla sosyal bilimlerden seçilmiş, basitleştirilmiş ve düzenlenmiş konular, bilgiler bütünüdür”.

Ülkemizde 2005-2006 öğretim y1lından itibaren uygulamaya konulan sosyal bilgiler programında sosyal bilgilerin tanımı şu şekilde yapılmıştır: 
Sosyal Bilgiler, bireyin toplumsal varoluşunu gerçekleştirebilmesine yardımcı olması amacryla; tarih, coğrafya, ekonomi, sosyoloji, antropoloji, psikoloji, felsefe, siyaset bilimi ve hukuk gibi sosyal bilimleri ve vatandaşlı bilgisi konularını yansitan; ögrenme alanlarının bir ünite ya da tema altında birleştirilmesini içeren; insanın sosyal ve fizikî çevresiyle etkileşiminin geçmiş, bugün ve gelecek bağlamında incelendiği; toplu öğretim anlayışından hareketle oluşturulmuş bir ilkögretim dersidir (MEB 2005, 52).

Sosyal bilgiler kavramı ilk kez 1916 yılında Amerika Birleşik Devletleri (ABD)'de Milli Eğitim Derneğinin Orta Dereceli Okul Teşkilatlandırma Komisyonu Sosyal Bilgiler Komitesi tarafından kabul edilmiştir. Komite bu kavramı; "konusu doğrudan insan toplumunun teşkilatına ve gelişmesine toplumsal birliklerin bir parçası olması dolayıslyla insana dair bilgiler, sosyal bilgilerdir" ş̧eklinde tanımlamıştır. Daha sonraki yıllarda da bu kavram diğer bütün ülkelerde yaygınca kullanılmaya ve okul programlarında yer almaya başlamıştır (Köstüklü 1998, 9). Ülkemizde ise 1952 yılında toplanan 5. Milli Eğitim Şurasında, sosyal bilgiler dersinin ilköğretim ve ortaöğretim kurumlarında okutulması kararlaştırılmıştır (Sözer 1998, 16) 1962 yılında yayınlanan ilkokul program taslağında, Tarih, Coğrafya ve Yurt Bilgisi derslerinin yerine "toplum ve ülke incelemeleri" dersi konulmuştur (Sönmez 1997, 23) Bu ders 1968 yılında yayınlanan ilkokul programında, sosyal bilgiler adını almıştır. Dersin programı üzerinde, bu yıllarda ABD'de egemen olan "yeni sosyal bilgiler" akımının önemli bir etkisi olmuştur (Öztürk 2007, 73). 1970-1971 öğretim yılında sadece bazı ortaokulların birinci sınıflarında sosyal bilgiler taslak programının denenmesine karar verilmiştir. Bu uygulama sonraki yıllarda kademeli olarak devam etmiştir. Talim ve Terbiye Kurulunun kararıyla 4.,5.,6.,7, ve 8. sinıflar sosyal bilgiler programı geliştirilmiştir. 6., 7. ve 8. sınıf programı 1975-1976 yılında tüm ülkede uygulanmıştır. Birinci kademe sosyal bilgiler programının ise ders kitapları üç yıl süreyle okutulacağ1 için 1977-1978 yılının başından itibaren uygulanmaya başlanması uygun görülmüştür. Ancak ortaokullarda okutulan sosyal bilgiler dersi 1985 yilında Talim ve Terbiye Kurulunun kararıyla kaldırılmıştır. 1985-1986 yılından sonra milli tarih, milli coğrafya ve vatandaşlık bilgileri adı altında üç derse ayrılmıştır. 1997-1998 öğretim yılında tekrar ilköğretim okullarının 6. ve 7. sınıflarında sosyal bilgiler dersi uygulamasına geçilmiştir (Güngördü 2001, 132).

Sosyal bilgiler dersinin temel amacı, öğrencilerin çevreye, topluma ve insanlığa karşı görev ve sorumluluklarını öğrenmesi, toplumsal sorunlara çözüm üretebilmesi ve toplumsal sorumlulukları yerine getirebilmesi amacıyla da onlara belli beceri ve davranışları kazandırmaktır (Aykaç 2007, 47). Bu amaçlar doğrultusunda, 2004 yılında oluşturmacı yaklaşıma göre tasarlanmış yeni sosyal bilgiler öğretimi programı ile öğrencinin yakın ve uzak çevresindeki sorunlara duyarlı, insan haklarına ve demokratik değerlere bağl1, sorgulayan, araştıran, problem çözen birey olarak yetişmesi hedeflenmektedir. Ayrıca programın öğrenciler tarafindan içselleştirilmesi ve öğrencilerin bu kazanımları yaşamlarına yansıtmaları beklenir (Doğanay 2008, 91).

\section{Sosyal Bilgiler Öğretiminde Değerler}

Değer kavramı Latince "klymetli olmak", "güçlü olmak" anlamlarına gelen valere kökünden türemiştir. Değer, sözlüklerde arzu edilen, ilgi duyulup peşinden koşulan, ayar ölçüsü olarak kullanılan şey anlamlarına gelmektedir (Aydın 2011, 39). Değer kavramı Türk Dil Kurumu'nun (TDK 2010) sözlügünde "bir şeyin önemini belirlemeye yarayan soyut bir ölçüt, bir şeyin değgiği karşıllk, klymet" şeklinde tanımlanmıştır. Değerler, bir sosyal grup veya toplumun kendi varlığını, birliğini, işleyişini ve devamını sağlamak için üyelerinin çoğunluğu tarafindan doğru ve gerekli olduğu kabul edilen ortak düşünce, amaç, temel ahlaki ilke ya da inançlardır ( $M E B$ 2010, 17). Değerler toplumlarla bireylerin tarafından önemsenen ve bunların sosyal ihtiyaçlarını karşılayan, davranışlarımıza yön veren ve genellikle iyi olduğuna inanılan güdülerdir (Özgüven 1994, 37). En genel anlamıyla değerler, insanların davranışlar karşısında iyi ya da kötü yargılarıdır. 
İlköğretimin genel hedefleri incelendiği zaman birçoğunun değer ifadesi olduğu görülmektedir. Bunların çoğu evrensel değer olarak kabul edebileceğimiz ve bütün toplumlarda önem atfedilen değerlerdir. Leming'e göre okullar var olduğu müddetçe değer öğretimi olacaktır. Çünkü okullar yapısı itibariyle zaten değer öğretirler (Sezer 2008, 2). Değerler öğrenilebilir ve öğretilebilir olgulardır. İnsan değerleri bilmiş olarak doğmamaktadır. Değerlerin öğrenilmesi rol öğrenme şeklinde bir sosyal öğrenmedir. Anne ve babalar çocukların ahlaki eğitiminden birinci derecede sorumluyken, ailenin ardından okul da toplumsal değerleri öğreten önemli bir kurumdur. Değerler eğitiminin amacı, çocuğun doğuştan getirdiği en iyi tarafi ortaya çıkarmak, kişiliğinin her yönüyle gelişmesini sağlamak, insani mükemmelliğe erişmesine yardımcı olmak, bireyi ve toplumu kötü ahlaktan korumak ve kurtarmak, bunun yanında iyi ahlakla donatmak ve devamını sağlamaktır (Aydın 2011, 5-6).

Değerler, toplumdaki bireylere hangi davranışların önemli olduğunu, nelere dikkat etmeleri gerektiğini ve kısaca hayatlarındaki en temel davranışların neler olduğunu öğretir. Eğitim kurumlarının genel hedeflerine bakıldığında birçoğunun vatansever olma, dürüst olma, temiz olma, sağlığına dikkat etme, düzenli olma, adil olma, hoşgörülü olma, adil olma, yaratıcı olma gibi birçok değeri kapsadığı görülmektedir. Eğitim kurumları bunlar ve benzeri değerler ile öğrencilere nelerin önemli olduğunu ve nasıl yaşanması gerektiği konusunda rehberlik eder (Akbaş 2004, 10). Örneğin, sosyal bilgiler öğretim programında toplumsal kurallar için çok önemli olduğu düşünülen bu değerlere yer verildiği görülmektedir. Cüceloğlu'na (1998) göre, insan davranışlarını yönlendiren değerler toplumsal baskı olmadan davranışa dönüşürler. Davranışlar ya zorunlu olarak, dış disiplinle yani başkalarının isteğiyle olur ya da kişinin kendi içselleştirdiği değerler vasıtasıyla olur. İnsan davranışını yönlendiren dış disiplin değil, iç disiplin yani değerler olmalıdır. Dıştan gelen davranışlar bir süre sonra kaybolur. Değerlerden kaynaklanan iç disiplin ise değer değişmediği sürece devam eder. Bu nedenle, iç disiplin her zaman daha etkilidir.

Sosyal bilgiler öğretiminde temel amaç, günümüz dünyasında çağdaş toplumlar seviyesine ulaşmak için bireylerin karşılaştıkları sorunları çözebilmeleri ve yaşadıkları kültürde çok yönlü eğitim ile ideal vatandaş düzeyine ulaşmalarını sağlamaktır. Bu anlamda sosyal bilgiler programlarının temel çıktısı ahlaki değer ve etik sistemine dayalı olarak kararlar alabilen, adalete sayg1 duyan, güzeli takdir eden ve düşünen bireyler yetiştirmektir (Baydar 2009, 15).

\section{Yaratıcı Drama}

Drama kavramıyla ilgili pek çok tanım yapılmıştır. Dramanın kelime anlamıyla ilgili Türk Dil Kurumu, Oxford, Redhouse sözlüğünde aşağıdaki tanımlara yer verilmiştir. TDK'nın Türkçe Sözlüğü'nde İtalyanca dramma, Fransızca drame olduğu belirtilen drama kelimesi için, sahnede oynanmak için yazılmış oyun; acıklı olayları, bazen güldürücü yönlerini de katarak konu alan sahne oyunu türü; tiyatro edebiyatı; (mecazi anlamda) acıklı olay şeklinde tanımlara yer verilmiştir. Oxford Sözlügü̈nde, bir sahne oyunu, dramatik sanat; Redhouse Sözlügü̈nde ise bir sahne oyununda olduğu gibi geçen hayat olayları olarak tanımlanır (Topçu 2008, 40). San (1990, 11)'e göre, drama sözcügü Yunanca “dran”dan türetilmiș olup, “yapmak, etmek, eylemek" anlamını taşımaktadır. Drama ise, bugünkü anlamına yakın bir şekilde, eylem anlamını taşımakta ve Yunanca dramenon'daki "seyirlik olarak benzetme" olgusuna dayanmaktadır. Drama kavramı, özellikle tiyatro bilimi çevresinde özetlenmiş, soyutlanmış eylem durumları anlamını kazanmıştır (San 1990, 11).

Nutku'ya (1990) göre; drama, insanın yaşamı boyunca süren bir eylemidir ve insanın kafaca sağlığına bağlıdır. Kısaca drama; "Yaşama sanatıdır". Drama, eğitim ve öğretimde yeni bir oluşumdur. Ezbere dayalı bir eğitim çocuğun zihinsel gelişimi, araştırma yapabilmesini, diğer insanlarla olan ilişkilerini, paylaşmayı ve nihayet etkili öğrenebilmesini engeller. Drama ise, 
çocuğun yaratııılığını geliştiren, yetiştiren ve onu hayata hazırlayan hem başlı başına bir eğitim alanı hem de etkili bir öğrenme yöntemidir (MEB 1999, 7). Drama, bir eylemin, olayın, bir duygunun çeşitli rollerin bir kavramın, konunun ya da öykünün, hatta şiirin canlı ya da cansız varlıkların sözel ve sözsüz, kendiliğinden davranışlarla, taklit yoluyla temsili olarak ifade edilmesi, canlandırılmasıdır (Önder 2005, 32). O’Neill ve Lombert $(1990,201)$ dramayı olaylar ve durumlarla bunların arasındaki bağlantıyı kolayca öğrenmeye aracılık eden bir öğretim yöntemi ve bununla birlikte hayal gücünü olabildiğince zenginleştiren bir çalışma alanı olarak tanımlamıştır.

Eğitimde yaratıcı dramanın kullanımına geçtiğimiz yüzyılda başlanmış, ilk yaratıcı drama dersleri 1911'de İngiltere'de gerçekleştirilmiştir. Yaratıcı drama kavramı İngiltere'de "eğitici drama" (Drama in Education), Almanya'da "okul oyunu" ya da "oyun ve etkileşim" (Schulspiel/ Spiel und Interaktion), ABD' de ise Türkiye'de olduğu gibi yaratıcı drama (creative drama) şeklinde tanımlanmıştır (Akoğuz \& Akoğuz 2011, 9).

Yaratıcı drama ile ilgili pek çok tanım yapılmıştır. San'a $(1995,3)$ göre, yaratıcı drama, "Doğaçlama ve role bürünme gibi tiyatro ya da drama tekniklerinden yararlanılan bir grup çalışması içindeki bireylerin bir yaşantı, eğitim ünitesi, soyut kavram ya da davranışı eski bilişsel örüntülerin yeniden düzenlenmesi yoluyla gözlem, deneyim, duygu ve yaşantıların gözden geçirildiği oyunsu süreçlerde anlamlandırılmasl, canlandırllmasıdır'. San'ın 1998'deki tanımına göre, "yaratıcı drama, önceden yazılmış bir metin olmaksızın katılımcıların kendi yaratıcı buluşları, özgün düşünceleri, öznel anıları ve bilgilerine dayanarak oluşturdukları eylem durumu ve doğaçlama canlandırmalarıdır".

Yaratıcı drama, özellikle Amerika'da Winifred Word ve Mccaslin gibi uzmanların; çocukların katıldıkları drama etkinliklerini tanımlamak için kullandıkları bir terimdir. Diğer bir yaklaşıma göre ise, yaratıcı drama, yaratıcılığı geliştirmek için çocuklarla yapılan drama etkinliklerini kapsar ve eğitici drama denilen eğitim tekniğinin bir alt türü olarak kabul edilebilir (Siks 1983 Akt. Önder 2010, 4). Yaratıcı drama, Amerika'daki en büyük tiyatro derneği ise yaratıcı dramayı şu şekilde açıklamıştır: "Doğaldır, yazılı bir metni yoktur. Sunuşsal değildir yani sahnelenmesi gerekmez, olay merkezlidir, lider tarafindan rehberlik edilen katılımcllar, yaşadıkları ve hayal ettikleri durumları yaratıcı drama şekli içinde yansitırlar. Lider grubun keşfetmesi, gelişmesi, fikirlerini, duygularını dramatik oyunlar yoluyla ifade etmesi için rehber olur" (Adıgüzel, 1993). Yaratıcı drama, oyunlar kurarak çocuğa yaşantılar yoluyla yeni durumlara ve olaylara sağlıklı tepkiler vermesi ya da uyum sağlaması konusunda yardım etme sürecidir.

Yapılan çeşitli tanımlardan yola çıkarak yaratıcı dramanın özellikleri şu şekilde sıralanabilir:

- Önceden yazılmış bir metin yoktur.

- Doğaçlama, rol oynama gibi tekniklerden yararlanır.

- Temelinde oyun vardır.

- Doğaldır, kalıplaştırılamaz.

- İzleyici yoktur, çocuklar hem oynar hem de gözleyerek empati kurarlar.

- Aktif katılımı sağlayarak, yaşantılar yoluyla öğrenmeye firsat tanır.

- Katılım, birliktelik, paylaşım ve gönüllülük esastır.

- Bilişsel, devinişsel ve duyuşsal alanlara hizmet eder.

Fidan'a (1986) göre öğretim yöntemi, öğrenciyi hedefe ulaştırmak için izlenen yoldur. Yöntemle, belli öğretme teknikleri ve araçları kullanılarak öğretmen ve öğrenci etkinliklerinin bir plana göre düzenlenmesi ve yürütülmesi amaçlanır. Sınıf içinde öğrenme-öğretme sürecinin etkili olabilmesi uygun yöntemlerin seçilmesiyle sağlanır. Bu nedenle, öğretmenin yöntem ko- 
nusunda seçici olabilmesi onların çok farklı yöntemleri tanımaları ve kullanabilmeleri ile mümkündür (Demirel 2007, 80).

Eğitimde dramanın bir yöntem olarak kullanılması çağdaş insanın toplumsal ilişkileri düzenlenmesine, kendini tanımasına, üretmesine ve varlığını sergilemesine olanak sağlamaktadır. Yaratıcı drama aracılığıyla olaylar ve durumlarla bunların arasındaki bağlantılar kolayca öğrenilebilir. Sosyolojik perspektiften bakıldığında bireyler, sadece kendileri değil, içinde yaşadıkları toplumun geçmişi, şimdiki zamanı, geleceği aynı zamanda insanlık hakkında da daha derinlemesine bilgi sahibi olabileceklerdir (O'Neill \& Lambert 1995; San 1996; Adigüzel 2006; Kara \& Çam 2007).

\section{Araştırmanın Amacı ve Önemi}

Değişen eğitim anlayışı çerçevesinde sosyal bilgiler programında öğrencilere doğrudan kazandırılması gereken çeşitli değerlere yer verilmiştir. Araştırmada öğretimi gerçekleşmesi amaçlanan değerlerden "hoşgörü" ve "duygu ve düşüncelere saygl" değerleri evrensel değerler olup, bütün toplumlarda yer alması gereken değerlerdendir. Yaratıcı drama, öğrencinin sürece aktif katılımını sağlayan, bilişsel, duyuşsal ve psikomotor becerilerini ortaya çıkaran yöntemlerden biri olarak bilinmektedir. Bu çalışmanın temel amacı, yöntem olarak yaratıcı drama kullanımının hoşgörü ile duygu ve düşüncelere saygı değerlerine etkisini araştırmaktır.

$\mathrm{Bu}$ genel amaç çerçevesinde, yöntem olarak yaratıcı drama kullanımının hoşgörü ile duygu ve düşüncelere saygı değerlerinin öğretiminde etkilerini değerlendirmek amacıyla aşağıdaki sorulara cevap aranmıştır.

- Kontrol grubunda yer alan öğrencilerin tutum ön test-son test puanları arasında anlamlı bir fark var midir?

- Deney grubunda yer alan öğrencilerin tutum ön test-son test puanları arasında anlamlı bir fark var midır?

- Kontrol ve deney gruplarında yer alan öğrencilerin tutum ölçeğinden aldıkları ön test puanları arasında anlamlı bir fark var mıdır?

- Kontrol ve deney gruplarında yer alan öğrencilerin tutum ölçeğinden aldıkları son test puanları arasinda anlamlı bir fark var midir?

- Yöntem olarak yaratıcı drama kullanılmasının, ilkokul 4. sınıf sosyal bilgiler öğretim programındaki "hoşgörü" ile "duygu ve düşüncelere saygl" değerlerinin öğretilmesinde etkisi nedir?

Yaratıcı dramanın yöntem olarak kullanılmasının çalışmalara örnek teşkil etmesi bakımından önemli görülmektedir. Aynı zamanda bu çalışmadan elde edilen bulguların program hazırlayıcılarına, ögretmenlere ve akademisyenlere çeşitli fikirler oluşturması bakımından yol göstereceği düşünülmektedir.

\section{Yöntem}

\section{Araştırmanın Deseni}

$\mathrm{Bu}$ çalışmada ön test-son test kontrol gruplu desen kullanılmış olup, deneysel çalışmayla elde edilen bilgiler nitel verilerle desteklenmiştir. Nicel araştırma verilerin daha çok sayısal bir şekilde ifade edildiği araştırmalardır. Punch'a $(2005,58)$ göre, nicel veriler hem sayım hem de ölçekleme ya da her ikisinin de birlikte kullanıldığı sayısal verilerdir. Yıldırım ve Şimşek'e $(2008,39)$ göre nitel araştırma ise, gözlem, görüşme ve doküman analizi gibi nitel veri toplama yöntemlerinin kullanıldığı, algıların ve olayların doğal ortamda gerçekçi ve bütüncül bir biçimde ortaya konmasına yönelik nitel bir sürecin izlendiği araştırma olarak tanımlanır. Hem nitel hem de nicel araştırmalarda farklı metot, yöntem veya teknikler kullanılsa da aslında 
birbirini tamamlayan niteliktedir. Nicel veriler tek başına kullanıldığında katılımcıların öznel dünyasını yakalamada yetersiz kalabilmektedir. $\mathrm{Bu}$ sebeple araştırmanın nitel boyutu aradaki boşluğu doldurmak için bir araç olabilir (Yıldırım \& Şimşek 2008, 39).

Howitt'e (1997) göre, ön test-son test kontrol gruplu desen (ÖSKD), yaygın kullanılan kar1şık bir desendir. Katılımcılar, deneysel işlemden önce ve sonra bağımlı değişkenle ilgili olarak ölçülürler. Kerlinger (1973), ÖSKD'yi kısaca kontrol ve deney gruplarına yansız olarak atanan deneklerin deneysel manipülasyonundan önce ve sonra ölçüldüğü desen olarak tanımlamaktadır (Büyüköztürk 2011, 919-920).

\section{Çalışma Grubu}

Çalışma, 2012-2013 eğitim-öğretim yılı bahar yarıyılında bir devlet ilkokulunda okuyan 4. sınıf öğrencilerine uygulanmıştır. Çalışma grubu, bu okulda okuyan, 4. sınıf şubesinden rastgele seçilen deney grubunda 11, kontrol grubunda 11, toplam 22 öğrenciden oluşmaktadır. Çalışmada, iki gruptan birisi deney (ağırlıklı olarak yaratıcı drama yöntemi uygulanan), diğeri kontrol (yaratıcı drama yöntemi uygulanmayan) grubu olarak belirlenmiştir.

Deney ve kontrol grubu öğrencilerine, çalışmanın geçerlik ve güvenirliğini artırmak için öğrenci tanıma formu uygulanmıştır. Yine aynı gruba, seçilen öğrencilerin "hoşgörü" ile "duygu ve düşüncelere saygl" değerlerine olan tutumlarını belirlemek amacıyla çalışma öncesinde ve sonrasında tutum ölçeği testi yapılmıştır. Deney grubuna "hoşgörü", "duygu ve düşüncelere saygl" değerleriyle ilgili yaratıcı drama yöntemi uygulanmıştır. Kontrol grubuna ise yaratıcı drama yöntemi uygulanmamıştır (Tablo 1).

Tablo 1. Deney Deseni

\begin{tabular}{lccc}
\hline Grubun Adı & Deney Öncesi & Deney Süreci (Denel İşlemler) & Deney Sonrası \\
\hline Kontrol Grubu & Öntest & Yaratııı Drama Yöntemi Uygulanmadı. & Sontest \\
\hline Deney Grubu & Öntest & Yaratıcı Drama Yöntemi uygulandı. & Sontest \\
\hline
\end{tabular}

\section{Verilerin Toplanması}

\section{Tutum Ölçeği}

Araştırmada kullanılan ölçek Çalışkan \& Sağlam (2012) tarafindan geliştirilmiştir. Araştırmada kullanılan Likert tipi ölçekte, açımlayıcı faktör analizi sonucunda toplam varyansın \% 47.97'sini açıklayan, üç alt faktörden oluşan 18 maddelik bir ölçme aracı elde edilmiştir. Bu alt faktörler "değer", "kabul" ve "empati"dir. Ölçeğin tamamı için hesaplanan iç tutarlılık güvenirlik katsayısının .89; birinci faktör için .86, ikinci faktörü için .70 ve üçüncü faktör için ise .63 olduğu tespit edilmiştir. Ölçeğin test-tekrar test güvenirlik katsayısının .84; birinci faktör için .83, ikinci faktör için .73 ve üçüncü faktör için .82; alt ölçeklerin madde-toplam korelasyonlarının .43 ile .63 arasında değiştiği ve \%27'lik alt-üst grupların ortalamaları arasındaki tüm farkların anlamlı olduğu belirlenmiştir (Çalışkan \& Sağlam 2012, 1431).

\section{Odak Grup Görüşmesi}

$\mathrm{Bu}$ araştırmada öğrencilerle her oturum sonrası odak grup görüşmeleri yapılmış ve yapılan bu görüşmeler analiz edilmiştir. Bireysel görüşmeler yanında odak grup görüşmeleri de, nitel veri toplamada önemli bir işleve sahiptir. Yıldırım \& Şimşek'e (2008, 153) göre, odak grup görüşmesi, 1lımlı ve tehditkâr olmayan bir ortamda önceden belirlenmiş bir konu hakkında algıları elde etmek amacıyla dikkatle planlanmış bir tartışmalar serisi olarak tanımlanır. Başka bir deyişle, bir konu, ürün veya hizmet hakkında insanların ne düşündüğünü ve ne hissettiğini 
anlamak odak grup görüşmesinin temel amacıdır. Temel olarak görüşme formatı kullanılmasına rağmen odak grup yoluyla kısa bir süre içinde onlarda katılımcıya ulaşmak mümkündür. Grup süreçlerinin, örneğin bireysel görüşmelere karşı dinamizmi ve yaratıcılığı nedeniyle odak grup görüşmeleri yoluyla araştırmanın problemleri hakkında daha derin ve zengin bilgiye ulaşmak olasıdır (Kruger \& Caser 2000; Yıldırım \& Şimşek 2008, 163).

\section{Günlükler}

Öğrenciler her ders sonrasında o dersle ilgili öğrendiklerini, duygularını ve yorumlarını içeren günlük tuttular. Araştırma sürecinde öğretmen, öğrenciler ya da araştırmaya katılan diğer bireylerden bir uygulama ya da sorunla ilgili günlük tutmaları istenebilir. Günlükler bireysel gözlemlere, duygulara, tepkilere, yorumlara ve açıklamalara ulaşmada yararlı olabilirler (Yıldırım \& Şimşek 2008, 301).

\section{İșlem Basamakları}

Araştırmada aşağıdaki işlemler gerçekleştirilmiştir:

- Uygulamaya başlamadan önce, 22 öğrenciye, "birey ve toplum" öğrenme alan1, "kendimi tanlyorum" ünitesindeki , "hoşgörü “, "duygu ve düşüncelere saygl" değerleriyle ilgili tutum ölçeği uygulanmıştır. Süre olarak bir ders saati verilmiştir.

- Uygulama öncesinde yaratıcı drama ağırlıklı ders planlarının hazırlanma sürecinde ilgili literatürden (Adıüzel 2006; Yalçınkaya, Sever \& Mazman 2009; Önder 2010; Üstündağ 2010; Akoğuz \& Akoğuz 2011) yararlanma yoluna gidilmiştir.

- Yaratıcı drama planları için uzman görüşü alındıktan sonra gerekli değişiklikler yapılarak son hali verilmiştir. Pilot uygulaması yapılmıştır. Dörder saatlik 4 ayrı yaratıcı drama planı hazırlanmıştır. Doğaçlama, rol aynama, rol değiştirme, paralel çalışma, donuk imge, istasyon, hikâye tamamlama gibi teknikler kullanılmıştır

- Deney ve kontrol grupları yansız atama yöntemiyle belirlenmiştir.

- Uygulama esnasında deney grubuna "birey ve toplum" öğrenme alanı, "kendimi tanıyorum" ünitesinde hoşgörü ve saygı değeriyle ilgili kazanımı vermek üzere, 4 hafta ve 16 saatlik süreyle, yaratıcı drama yöntemi uygulanmıştır. Kontrol grubuna ise yaratıcı drama yöntemi uygulanmamıştır. Kontrol grubundaki öğrencilere ders kitabının ve öğretim programının öngördüğü yöntem ve teknikler uygulanmıştır.

- Deney grubu öğrencilerini yönteme hazırlamak amaciyla uygulamaya başlamadan önce, öğrenciler yaratıcı drama yöntemiyle ilgili bilgilendirilmişlerdir. Yaratıc1 drama basamakları hakkında örnek olması için, 1sınma, dans, oyun, doğaçlama, pandomim, kukla draması, rahatlama çalışmaları ve sonuç etkinlikleriyle ilgili çalışmalar yapılmıştır.

- Deney ve kontrol grubu öğrencilerine etkinliklerde iletişimin kuvvetli olması amacıyla, tanıma formu uygulanmıştır.

- Yaratıcı drama planları araştırmacı tarafından, öğrencilerin seviyelerine uygun olarak hazırlanmıştır.

- Yaratıcı drama dersleri okulun ana sınıfinda uygulanmıştır. Ders sırasında tahta, masa, sandalye, oyuncak, kalem, kağıt, hikaye kitabı, minder vb. materyaller araçgereç olarak kullanılmıştır.

- Öğretmen gerek olduğunda grup sayılarını eşitlemek amacıyla etkinliğin bir parçası olarak yaratıcı drama sürecine katılmıştır. Ancak etkinliklerin düzenlenmesinde yer almamıştır. 
- Deney grubuna yaratıcı drama yöntemiyle uygulanan derslerin video kaydı yapılmıştır ve yaratıcı dramanın aşamalarıyla ilgili fotoğraf çekimi yapılmıştır.

- Öğrencilere uygulama sonrasında değerlerle ilgili tutumlarını ölçmek amacıyla 18 soruluk, 5'li ölçek son test olarak uygulanmıştır. Süre olarak 1 ders saati verilmiştir. Deney grubunda, her ders sonrasında, öğrencilere günlük tutturulmuştur.

- Deneyin öğretim süresi, 4 hafta süreyle, 16 ders saatinde tamamlanmıştır.

- Uygulamalar, kontrol ve deney grubuna araştırmacı tarafından yapılmıştır.

\section{Veri Analizi}

Araştırma kapsamında tutum ölçeğiyle toplanan veriler, SPSS 15.0 paket programı ile çözümlenmiştir. Araştırmaya katılan öğrencilerin ölçeğe verdiği cevaplar ile oluşturulan alt problemlere ilişkin bulgular Mann Whitney U, Wilcoxon işaretli sıralar testi ile analiz edilmiştir. Araştırma sürecinde odak grup görüşmesi ve günlükler ile toplanan nitel veriler içerik analizi ile değerlendirilmiştir.

İçerik analizi, toplanan verilerin derinlemesine analiz edilmesini gerektirir ve önceden belirgin olmayan temaların ve boyutların ortaya çıkarılmasına olanak tanır. İçerik analizinde temelde yapılan işlem, birbirine benzeyen verileri belirli kavramlar ve temalar çerçevesinde bir araya getirmek ve bunları okuyucunun anlayabileceği bir biçimde düzenleyerek yorumlamaktır (Yıldırım \& Şimşek 2008, 227).

Öğrencilerin odak grup görüşmesi ve günlüklerinden dikkate değer bulunanlar, hiçbir değişiklik yapılmadan doğrudan alıntı şeklinde verilmiştir. Nitel bulgular yazıya dökülürken cinsiyet ve kod numaraları kullanılarak kayda geçirilmiştir. Örneğin, öğrenciler cinsiyet ve kod numaraları kullanılarak EÖ1, KÖ1 şeklinde kodlanmıştır.

\section{Bulgular ve Yorumlar}

\section{Nicel Verilerden Elde Edilen Bulgular}

Deney ve kontrol grubu öğrencilerinin "hoşgörü tutum ölçeği”" ön testinden aldıkları puanların, Mann Whitney $U$ testi analiz sonuçları Tablo 2'de verilmiştir.

Tablo 2. Kontrol ve Deney Gruplarında Yer Alan Öğrencilerin Tutum Ölçeğinden Aldıkları Ön Test Puanlarının Karşılaştırılması İle İlgili Sonuçlar

\begin{tabular}{lcccccc}
\hline Grup & $\mathbf{N}$ & $\bar{X}$ & $\begin{array}{c}\text { Sira } \\
\text { ortalaması }\end{array}$ & $\begin{array}{c}\text { Sira } \\
\text { Toplamı }\end{array}$ & $\mathbf{U}$ & P \\
\cline { 1 - 4 } Kontrol & 11 & 76,18 & 10,73 & 118,00 & \multirow{2}{*}{52,000} & 0,576 \\
\cline { 1 - 5 } Deney & 11 & 73,18 & 12,27 & 135,00 & & $\mathrm{p}>0,05$ \\
\hline
\end{tabular}

Tablo 2'deki istatistiksel verilere bakıldığında, deney ve kontrol gruplarında yer alan öğrencilerin, hoşgörü tutum ön test puanları arasında anlamlı düzeyde bir fark olmadığı tespit edilmekte$\operatorname{dir}(U=52,000 ; p>0,05)$. Bu verilere göre, öğrencilerin uygulama öncesi tutum ön test puanlar1 benzerlik göstermektedir. Bu sebeple, kontrol ve deney grubundaki öğrencilerin tutumlarının birbirine yakın seviyede olduğu görülmektedir.

Kontrol grubunda yer alan öğrencilerin ön-test ve son-test puanları arasında fark olup olmadığını incelemek amacıyla Wilcoxon işaretli sıralar testi uygulanmış ve bulgulara Tablo 3'te yer verilmiştir. 
Tablo 3. Kontrol Grubu'nda Yer Alan Öğrencilerin Tutum Ön Test-Son Test Puanlarının Karşılaştırılmasına İlişkin Sonuçları

\begin{tabular}{lccccc}
\hline $\begin{array}{l}\text { Son test } \\
\text { Ön test }\end{array}$ & $\mathbf{n}$ & $\begin{array}{c}\text { Sira } \\
\text { ortalaması }\end{array}$ & $\begin{array}{c}\text { Sıra } \\
\text { toplamı }\end{array}$ & $\mathbf{Z}$ & $\mathbf{P}$ \\
\hline Negatif sıra & 6 & 6,50 & 39,00 & 1,173 & 0.241 \\
\hline Pozitif sıra & 4 & 4,00 & 16,00 & $\mathrm{p}>0,05$ \\
\hline Eşit & 1 & & & \\
\hline
\end{tabular}

Tablo 3 verilerine göre, kontrol grubunun hoşgörü tutum ön test ve son test puanları arasında anlamlı bir fark bulunmamaktadır $(\mathrm{z}=1,173 ; \mathrm{p}>0,05)$.

Deney grubunda yer alan ögrrencilerin ön-test ve son-test puanları arasında fark olup olmadığını incelemek amacıyla Wilcoxon işaretli sıralar testi uygulanmış ve bulgulara Tablo 4 'ta yer verilmiştir.

Tablo 4. Deney Grubu'nda Yer Alan Öğrencilerin Tutum Ön Test-Son Test Puanlarının Karşılaştırılmasına İliş̧kin Sonuçları

\begin{tabular}{lccccc}
\hline $\begin{array}{l}\text { Son test } \\
\text { Ön test }\end{array}$ & $\mathbf{n}$ & $\begin{array}{c}\text { Sıra } \\
\text { ortalaması }\end{array}$ & Sıra toplamı & $\mathbf{Z}$ & $\mathbf{P}$ \\
\cline { 1 - 4 } Negatif sıra & 3 & 2,83 & 8,50 & \multirow{2}{*}{1.193} & $\begin{array}{c}0,053 \\
\mathrm{p}>0,05\end{array}$ \\
\cline { 1 - 5 } Pozitif sıra & 7 & 6,63 & 46,50 & & \\
\hline Eşit & 1 & & & & \\
\hline
\end{tabular}

Tablo 4'te, deney grubunun hoşgörü tutum ön test ve son test puanları arasında anlamlı bir fark bulunmadığı görülmektedir $(\mathrm{z}=1,193 ; \mathrm{p}>0,05)$. Fakat deney grubunda yer alan öğrencilerinin uygulama sonrasındaki son test puan ortalamalarının ön test puan ortalamalarından yüksek olduğu tespit edilmiştir (ön test $\bar{X}=73,18$; son test $\bar{X}=80,18$ ).

Deney ve kontrol grubu öğrencilerinin "hoşgörü tutum ölçeği” ön testinden aldıkları puanların, Mann Whitney $U$ testi analiz sonuçları Tablo 5 'te verilmiştir.

Tablo 5. Kontrol ve Deney Gruplarında Yer Alan Öğrencilerin Tutum Ölçeğinden Aldıkları Son Test Puanlarının Karşılaştırılması İle İlgili Sonuçlar

\begin{tabular}{lcccccc}
\hline Grup & $\mathbf{N}$ & $\bar{X}$ & $\begin{array}{c}\text { Sira } \\
\text { ortalaması }\end{array}$ & $\begin{array}{c}\text { Sira } \\
\text { Toplamı }\end{array}$ & $\mathbf{U}$ & P \\
\hline Kontrol & 11 & 69,55 & 8,55 & 94,00 & \multirow{2}{*}{28,000} & 0,033 \\
\cline { 1 - 5 } Deney & 11 & 80,18 & 14,45 & 159,00 & & $\mathrm{p}>0,05$ \\
\hline
\end{tabular}

Tablo 5 verilerine göre, deney ve kontrol gruplarının demokratik tutum son test puanları arasında anlamlı düzeyde bir farklılık bulunmaktadır $(\mathrm{t}=2.172 ; \mathrm{p}<0.05)$. Bu sonuca göre; uygulama sonrasında drama ağırlıklı yürütülen etkinliklerin öğrencilerin hoşgörü tutumlarını artırmada geleneksel öğretim yöntemlerine göre daha etkili olduğu söylenebilir.

\section{Nitel Verilerden Elde Edilen Bulgular}

Odak grup görüşmelerinden elde edilen bulgulara aşağıda yer verilmiştir:

Diyalog: Duygu ve Düşüncelere Saygı

AÖ: Her insan aynı mıdır?

KÖ3: Her insan aynı değildir. Mesela her insanın farklı bir özelliği vardır. Bazı insanlar 
mavi gözlüdür, bazıları siyah, bazıları kahverengi gözlüdür. Sadece dış görünüş değil, iç dünyaları da farklıdır. Duygu, düşünce ve saygı gibi.

KÖ8: Farkl11ıklar vardır. Birinin kilosu 25, birinin 27'dir. Bazı insanlar et sever, bazı insanlar makarna sever.

KÖ2: Birisi kötü resim yapıyor, birisi iyi resim yapıyor.

EÖ11: Birisi yalancı, birisi yalancı değildir. Benim saçım siyah, İsmail'in saçı kahverengidir.

EÖ9: Yetenekleri farklıdır. Biri çalışkandır, birisi tembeldir.

KÖ1: Fiziksel özellikleri ve duygu, düşünceleri farklıdır.

KÖ10: Birisinin saç rengi siyah, birisinin kahvedir.

KÖ7: Saç renkleri farkl1, birisinin siyah, biri sarı, birisi kahvedir.

Yukarıdaki cevaplar incelendiğinde, duygu ve düşüncelere saygıyla ilgili ön bilgilerini harekete geçirmek amacıyla sorulan soruya öğrenciler her insanın farklı olduğunu söyleyerek cevap vermişlerdir. EÖ9 adlı öğrenci "Yetenekleri farklıdır. Biri çalışkandır, birisi tembeldir", KÖ1 adlı öğrenci "Fiziksel özellikleri ve duygu, düşünceleri farklıdır", KÖ10 adlı öğrenci "Birisinin saç rengi siyah, birisinin kahvedir", KÖ8 adlı öğrenci " Farklılıklar vardır. Birinin kilosu 25, birinin 27'dir. Bazı insanlar et sever, bazı insanlar makarna sever" söylemleri öğrencilerin her insanın farklı olduğunu düşündüklerini ortaya koymaktadır.

Etkinlikte yer alan diğer bir giriş sorusu ise "İnsanların başka insanlardan farklı olmasını sağlayan özelikler nelerdir? " sorusudur.

KÖ1: Duyguları farklidır.

Bu cevabı destekleyen görüşler şu şekildedir:

KÖ3: Bazı insanlar sevinir, bazı insanlar ağlar.

KÖ8: Davranışları farklıdır.

KÖ10: Düşünceleri farklıdır.

$\mathrm{Bu}$ cevabı destekleyen görüşler:

KÖ2: Aysun Elvan'1 iterse, Elvan ben de Aysun'u iteyim diye düşünebilir.

KÖ3: Elvan kızdır. Duygusu çok kızması, düşüncesi ise keşke Aysun hatasını anlasa da affetsem olabilir.

KÖ5: Yetenekleri farklıdır.

$\mathrm{Bu}$ cevabı destekleyen görüşler:

EÖ11: Bazıları takla atabilir, bazıları atamaz.

EÖ9: Bazıları şarkı söyler, bazıları dans eder.

KÖ3: Birisi arkadaşım çok güzel resim yapıyor, ben yapamıyorum diye düşünebilir. Ama hem kendine, hem de karşısındakine haksızlık etmiş olur. Çünkü yeteneği olmayabilir.

EÖ4: Fiziksel özellikleri farklıdır.

Öğrencilerin vermiş oldukları cevaplara bakıldığında, öğrenciler insanların başka insanlardan farklı olmasını sağlayan özellikleri duygu, düşünce, yetenek, davranış, fiziksel özellikler diye belirtmişler ve örnek vererek cevaplarını desteklemişlerdir. Duygu ve düşüncelere sayg1 değerini ortaya çıkarmak için sorulan ön bilgileri harekete geçirici sorulardan sonra öğrencilere "Bireysel farklılık nedir?" sorusu sorularak tanımı oluşturmaları sağlanmıştır.

EÖ4: Duygu, düşünce, yetenek, fiziksel özellik ve davranışlar birbirinden farklıdır.

Doğaçlamalardan sonra öğrencilere doğaçlamalarla ilgili neler öğrendikleri sorulduktan 
sonra genel olarak "Bir insan hakkında olumlu düşüncelere sahip değilsek ona nasıl davranmalıyız?" sorusu yöneltilmiştir.

EÖ11: İyi davranmalıyı.

EÖ4: Saygılı olmalıyı.

KÖ3: Saygılı davranmalıyız.

KÖ1: Duygu ve düşüncelere saygılı davranmalıyız.

Öğrenci cevaplarına bakıldığında öğrencilerin, farklı duygu ve davranışlara karşı saygılı davranmaları gerektiğini kavradıkları görülmektedir. Bir diğer soru ise "Farklı düşüncelere sahip insanlara karşı nasıl davranılmalıdır?" sorusudur.

KÖ8: Ona karşı saygılı davranırım.

KÖ3: Saygilı davranırım.

EÖ9: Sayg1lı davranmalıyı.

EÖ4: O bana kötü davransa bile saygılı davranırım. Herkes farklı düşüncelere sahiptir.

KÖ1: Herkesin davranışlarına, duygu ve düşüncelerine saygılı davranmalıyız. Bizden farklı düşünen birisini dövmemeliyiz.

Öğrenci cevapları incelendiğinde, EÖ4 adlı öğrenci "O bana kötü davransa bile saygılı davranırım. Herkes farklı düşüncelere sahiptir." ve KÖ1 adlı öğrenci "Herkesin davranışlarına, duygu ve düşüncelerine saygll davranmalıyı. Bizden farklı düşünen birisini dövmemeliyiz" söylemleri öğrencilerin farklı düşüncelere sahip insanlara ne durumda olursak olalım saygıyla yaklaşmaları gerektiğini kavradıklarını göstermektedir.

Etkinliğin son sorusu "Bu derste neler ögrendin?" sorusudur.

KÖ3: Herkes farklı düşüncelere sahiptir. Sayg1lı olmalıyız.

KÖ2: İnsanlara karşı saygılı ve sevgili davranmalıyız.

KÖ5: Bireysel farklılıkları olan insanlara saygılı davranırım.

KÖ10: Fiziksel özelikleri, duygu ve düşünceleri öğrendim.

KÖ1: Duygu, düşünce, sayg1, sevgiyi öğrendim.

KÖ3: Bireysel farkl11ıklara sayg1 göstermeliyiz.

EÖ9: Saygıyı ve sevgiyi öğrendim.

KÖ1: Olumlu ve olumsuz düşünceleri öğrendim.

Yukarıdaki diyaloglar etkinliğin genel değerlendirme sorularıdır. Öğrencilerin her insanın farklı olduğunu bildiklerini, bu farklılıkların bireysel farklılık olduğunu anladıklarını, bireysel farkl1lıkları tanıyarak kabul ettiklerini ve bireysel farklılıklara karşı saygılı olmamız gerektiğini kavradıklarını kanıtlar niteliktedir. 


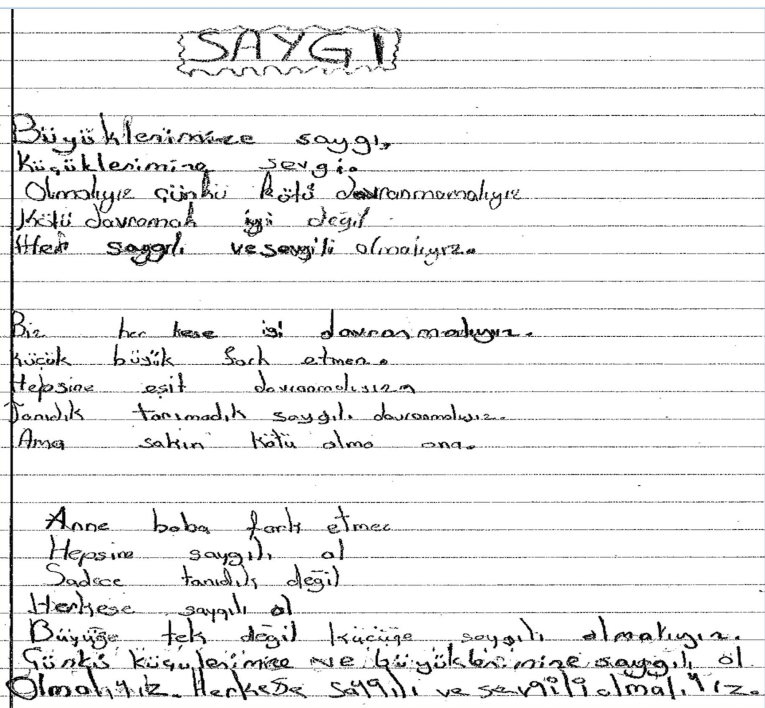

Fig. 1. İstasyon Çalışması Şiir Etkinliği

Yukardaki ekinliğe (Fig. 1) baktığımızda, öğrenciler herkese saygıyla yaklaşmamız gerektiğini vurgulamışlardır.

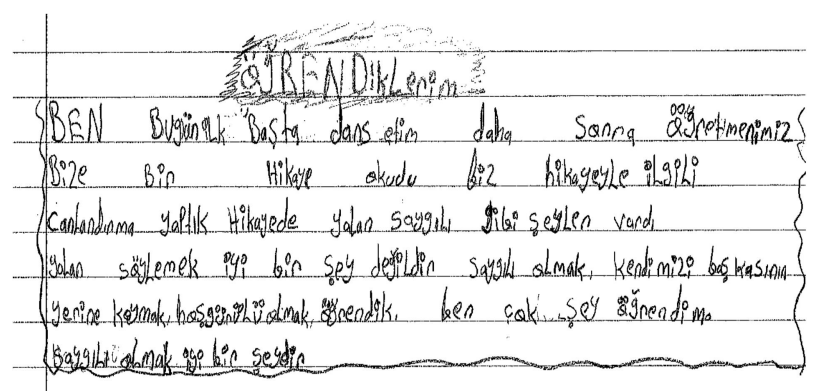

Fig. 3. Bir Öğrencinin Günlüğünden Örnek

Yukarıdaki KÖ5 günlüğüne (Fig. 3) baktığımızda öğrencinin

"Yalan söylemek iyi bir şey değildir. Saygılı olmak, kendimizi başkasının yerine koymak, hoşgörülü olmak ögrendik. Saygılı olmak iyi bir şeydir" söylemi öğrencinin saygıyı ve hoşgörüyü kavradığını, bunun yanında yalanın kötü bir kavram olduğunu anladığını da göstermektedir. "Kendimizi başkasının yerine koymak" söylemiyle öğrencinin başkalarının duygu ve düşüncelerini anlayarak, aynı duyguları hissetmesi hoşgörülü olacağının kanıtıdır.

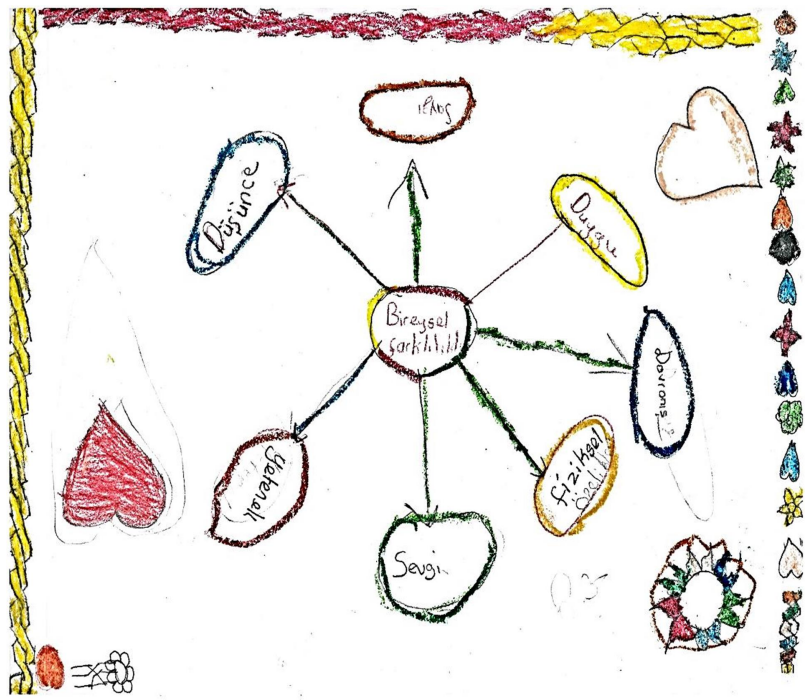

Fig. 2. İstasyon Çalışması Kavram Haritası Yukarıdaki kavram haritası (Fig. 2) incelendiğinde, öğrencilerin bireysel farklılıkların neler olduğunu kav radıklarını kanıtlar niteliktedir.

$\int_{0}^{0}$

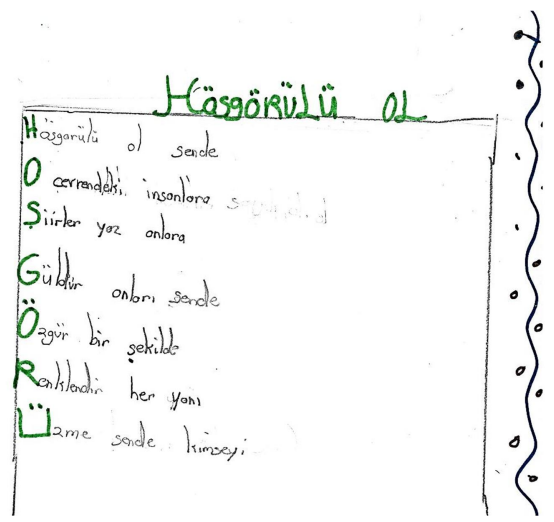

Fig. 4. Akrostiş Etkinlik Örneği

Figür 4'te akrostiş etkinliğinde bir öğrencinin hazırlamış olduğu çalışma yer almaktadır. Öğrenci gerçekleştirilen yaratıcı drama etkinlikleri sonrası öğrenmiş olduklarını değerlendirme imkânı bularak hoşgörü değeri ile ilgili duygu ve düşüncelerini ifade etmiştir.

\section{Sonuç ve Öneriler}

Araştırma bulguları doğrultusunda şu sonuçlara ulaşılmıştır:

- Deney ve kontrol gruplarında yer alan öğrencilerin, hoşgörü tutum ön test puanları arasında anlamlı düzeyde bir fark olmadığı tespit edilmiştir. Bu sebeple, kontrol ve deney grubundaki öğrencilerin tutumlarının birbirine yakın seviyede olduğu görülmektedir.

- Kontrol grubunun hoşgörü tutum ön test ve son test puanları arasında anlamlı bir fark bulunmamaktadir.

- Deney grubunun hoşgörü tutum ön test ve son test puanları arasında anlamlı bir fark bulunmadığı görülmektedir. Fakat deney grubunda yer alan öğrencilerin uygulama 
sonrasındaki son test puan ortalamalarının ön test puan ortalamalarından yüksek olduğu tespit edilmiştir (ön test $\bar{X}=73,18$; son test $\bar{X}=80,18$ ).

- Deney ve kontrol gruplarının tutum son test puanları arasında anlamlı düzeyde bir farklılık bulunmaktadır. Bu sonuca göre; uygulama sonrasında drama ağırlıklı yürütülen etkinliklerin öğrencilerin hoşgörü tutumlarını artırmada geleneksel öğretim yöntemlerine göre daha etkili olduğu söylenebilir.

- Hoşgörü ile duygu ve düşüncelere saygı değerlerinin öğrenmede yöntem olarak yaratıcı dramanın kullanımının etkili olduğu tespit edilmiştir.

- Yaratıcı drama etkinliklerine katılan 11 öğrencinin pek çoğunun hoşgörü değeri ile duygu ve düşüncelere saygı değerinin öğrendikleri belirlenmiştir.

- Etkinlik sonrasında öğrencilerin hoşgörü ve saygıyla ilgili davranışları kavradıkları, bireysel farklılıkları ve toplumsal farklılıkları kabul ettikleri, bireysel farklılıklara karşı saygılı olmayı ve iletişim kurarken karşımızdaki kişiye saygılı ve hoşgörülü olmayı, karşımızdaki insanı dikkatli bir şekilde dinlemeyi, görüşleri uymasa ve karşısındaki kişiyi sevmesek bile kendisini onun yerine koyarak duygu ve düşüncelerini anlayabilmeyi, hoşgörü ve saygının insanlar arasındaki iletişimde önemli olduğunu, sadece insanlara değil, hayvanlara da hoşgörülü ve saygıll davranmak gerektiğini kavradıkları tespit edilmiştir.

- Öğrencilerin yaratıcı drama yöntemiyle yaptıkları sosyal bilgiler dersine karşı olumlu tutum gösterdikleri, her etkinliğe zevkle katıldıkları ve dersleri yaparken eğlenerek ve yaşayarak öğrendikleri görülmüştür.

Elde edilen bu sonuçlar çerçevesinde aşağıdaki öneriler getirilebilir:

- Hoşgörü ile duygu ve düşüncelere saygi değerleri soyut değerlerdir. Bu değerler yaratıcı drama yönteminde kullanılan tekniklerle somutlaştırılmalı ve öğrencilere kazandırılmalıdır. Yaratıcı drama yöntemiyle öğrenciler daha rahat ve kalıcı bir şekilde bu değerleri öğrenebileceklerdir.

- Hoşgörü ile duygu ve düşüncelere saygı değerleri evrensel değerler olup, bir toplumda gelecek kuşaklara mutlaka aktarılması gereken değerlerdir. Bu değerlerin öğretimine daha fazla önem verilmelidir.

- Program şekillendirilirken ve ders kitapları hazırlanırken yaratıcı drama yöntemine ve araştırma sürecinde yapılan etkinliklere benzer etkinliklere yer verilebilir.

- Okullarda yaratıcı drama sınıfları hazırlanabilir ve yaratıcı drama sınıfında gerekli olabilecek ve değer öğretiminde kullanılacak malzemeler, araç-gereçler temin edilebilir.

- Öğretmenler derslerinde yaratıcı drama yöntemini kullanabilirler. Çünkü öğrenciler yaratıcı dramayla rahatlamakta ve ilgili kazanımı sadece dinleyerek değil, yaparak-yaşayarak öğrenmektedir.

- Araştırma İlkokul 4. sınıf sosyal bilgiler programında, Birey ve Toplum öğrenme alanında yer alan, hoşgörü ile duygu ve düşüncelere saygı değerleriyle sınırlandırılmıştır. Programdaki tüm değerler için yaratıcı drama planları hazırlanarak, bu yöntemle dersler işlenebilir.

- Yöntem olarak yaratıcı drama kullanımı sadece değerler öğretimi için değil, programdaki tüm kazanım, kavram ve beceri vb. için uygulanabilir.

- Yöntem olarak yaratıcı drama kullanımı, sadece sosyal bilgiler ders için değil, diğer derslerdeki kazanım, bilgi, beceri vb. öğretiminde de kullanılabilir.

- Yöntem olarak yaratıcı drama kullanımının ilkokul 5., 6., 7. ve 8. sinıf sosyal bilgiler öğretim programındaki değerlere etkisini araştıran araştırmalar yapılabilir.

- Yöntem olarak yaratıcı drama kullanımın ilkokul 4. sınıf ve diğer sınıflardaki diğer değerlere etkisini araştıran çalışmalar yapılabilir. 


\section{KAYNAKÇA}

Adıgüzel H. Ö. (2006). "Yaratıcı Drama Kavramı, Bileşenleri ve Aşamaları”. Yaratıcı Drama Dergisi 1/1 (2006) $17-27$.

Adıgüzel Ö. (1993). Oyun ve Yaratıcı Drama İlişkisi. Yayımlanmamış Yüksek Lisans Tezi. Ankara Üniversitesi Eğitim Bilimleri Enstitüsü, Ankara 1993.

Akbaş O. (2004). Türk Milli Eğitim Sisteminin Duyuşsal Amaçlarının (değerlerinin) İlköğretim 2. Kademedeki Gerçekleşme Derecesinin Değerlendirilmesi. Yayımlanmamış Yüksek Lisans Tezi. Gazi Üniversitesi Eğitim Bilimleri Enstitüsü, Ankara 2004.

Akfirat F. Ö. (2004). Yaratıcı Dramanın İşitme Engellilerin Sosyal Becerilerinin Gelişimine Etkisi. Yayımlanmamış Doktora Tezi. Ankara Üniversitesi Sosyal Bilimler Enstitüsü, Ankara 2004.

Akoğuz A. \& Akoğuz M. (2011). Yaratıcı Drama Etkinlikleri. İstanbul 2011.

Aydın M. (2011). "Değerler, İşlevleri ve Ahlak". Eğitime Bakış Dergisi 7/19 (2011) 39-45.

Aykaç N. (2007). "İlköğretim Sosyal Bilgiler Dersi Eğitim-Öğretim Programına Yönelik Öğretmen Görüşleri”. Elektronik Sosyal Bilimler Dergisi 6/22 (2007) 46-73.

Baydar P. (2009). İlköğretim Beşinci Sinıf Sosyal Bilgiler Programında Belirlenen Değerlerin Kazanım Düzeyleri ve Bu Süreçte Yaşanılan Sorunların Değerlendirilmesi. Yayımlanmamış Yüksek Lisans Tezi. Çukurova Üniversitesi Sosyal Bilimler Enstitüsü, Adana 2009.

Büyüköztürk Ş. (2011). Deneysel Desenler. Ankara 2011.

Cüceloğlu D. (1998). Anlamlı ve Coşkulu Bir Yaşam İçin Savaşçı. İstanbul 1998.

Çalışkan H. \& Sağlam H. İ. (2012). "Hoşgörü Eğilim Ölçeğinin Geliştirilmesi ve İlköğretim Öğrencilerinin Hoşgörü Eğilimlerinin Çeşitli Değişkenler Açısından İncelenmesi”. Kuram ve Uygulamada Ĕgitim Bilimleri Dergisi 12/2 (2012) 1431-1446.

Demirel Ö. (2007). Öğrenme Sanatı ve Öğretme. Ankara 2007

Doğanay A. (2008). "CCağdaş Sosyal Bilgiler Anlayışında Yeni Sosyal Bilgiler Programının Değerlendirilmesi”. Çukurova Üniversitesi Sosyal Bilimler Enstitüsü Dergisi 17/2 (2008) 77-96.

Fidan N. (1986). Okulda Öğrenme ve Öğretme. Ankara 1986

Güngördü E. (2001). Illköğretimde Hayat Bilgisi ve Sosyal Bilgiler Öğretimi. Ankara 2001.

Howitt D. \& Cramer D. (1997). An Introduction to Statics in Psychology. London 1997.

Kara Y. \& Çam F. (2007). "Yaratıcı Drama Yönteminin Sosyal Beceri Kazandırmada Etkisi". Hacettepe Üniversitesi Eğitim Fakültesi Dergisi 32 (2007) 144-155.

Kerlinger F. N. $\left(1973^{2}\right)$. Foundations of Behavioral Research. London 1973.

Kıyıcı F. (2002). Sosyal Bilgiler Ders Kitaplarında İçeriğin Hazırlanması. Yüksek Lisans Tezi. Atatürk Üniversitesi, Sosyal Bilimler Enstitüsü, Erzurum 2002.

Köken N. (2002). "Sosyal Bilgiler Kavramı Üzerine Bazı Düşünceler". Sosyal Bilimler Enstitüsü Dergisi 8 (2002) 235-246.

Köstüklü N. (1998). Sosyal Bilgiler ve Tarih Öğretimi. Konya 1998.

MEB (2010). İlköğretim Sosyal Bilgiler Dersi 4-5 Sinıflar Öğretim Programı ve Kılavuzu Bilgiler. Ankara 2010.

MEB (1999). Illköğretimde Drama. Ankara 1999.

MEB (2005). İlkögrretim Sosyal Bilgiler Dersi 6-7 Sinıflar Öğretim Programı ve Kılavuzu. Ankara 2005.

Nutku Ö. (1990). Oyun, Çocuk ve Tiyatro. İstanbul 1990.

O’Neill C. \& Lambert A. (1990). Drama Structures: A Practical Handbook For Teachers. London 1990.

Önder A. (2005). "Okul Öncesinde Drama Sonrasındaki Etkinlikler, Çocukta Yaratıcllı ve Drama”. Ed. A. Öztürk. Eskişehir 2005.

Önder A. (2010). Yaşayarak Öğrenme İçin Eğitici Drama. Ankara 2010.

Özgüven İ. E. (1994). Psikolojik Testler. Ankara 1994.

Öztürk C. (2007). "Sosyal Bilgiler: Toplumsal Yaşama Disiplinler Arası Bir Yaklaşım”. Ed. C. Öztürk, Hayat Bilgisi ve Sosyal Bilgiler Öğretimi Yapılandırmacı Bir Yaklaşım (2007) 21-50. Ankara. 
Punch K. F. (2005). Sosyal Araştırmalara Giriş Nicel ve Nitel Yaklaşımlar. Ankara 2005.

San İ. (1996). Eğitim- Öğretimde Yaşayarak Öğrenme Yöntemi ve Estetik Süreç Olarak Yaratıcı Drama. Eğitimde Nitelik Geliştirme 1. Seтроzуuтu (13-14 Nisan 1991).

San İ. (1990). "Eğitimde Yaratıı Drama". Eğitim Bilimleri Fakültesi Dergisi 23/2 (1990) 573-574.

San İ. (1996). "Yaratıcılığı Geliştiren Bir Yöntem ve Yaratıcı Drama Bireyi Yetiştiren Bir Disiplin: Eğitsel Yaratıcı Drama". Yeni Türkiye Dergisi 7 (1996) 148-160.

Sever R., Yalçınkaya E. \& Mazman F. (2009). "Sosyal Bilgiler Öğretiminde Etkili Bir Öğrenme Yöntemi: Dramatizasyon”. Atatürk Üniversitesi Sosyal Bilimler Enstitüsü Dergisi 13/1 (2009) 155-166.

Sezer T. (2008). İlköğretim 6. Sinıf Sosyal Bilgiler Dersinde Sorumluluk Değerinin Öğretimine İlişkin Öğretmen Görüşleri. Yayımlanmamış Yüksek Lisans Tezi. Gazi Üniversitesi Eğitim Bilimleri Enstitüsü, Ankara 2008.

Sönmez V. (1997). Sosyal Bilgiler Öğretimi ve Öğretmen Kılavuzu. Ankara 1997.

Sözer E. (1998). Kuramdan Uygulamaya Sosyal Bilimlerin Öğretimi. Eskişehir 1998.

TDK (2010). Türk Dil Kurumu, Büyük Türkçe Sözlük. Ankara 2010.

Topçu A. K. (2008). Görsel Sanatlar Eğitiminde Bir Öğretim Yöntemi Olarak Yaratıcı Drama. Yayımlanmamış Yüksek Lisans Tezi. Selçuk Üniversitesi, Sosyal Bilimler Enstitüsü, Konya 2008.

Üstündağ T. (2010). Yaratıcı Drama Öğretmeninin Günlügü. Ankara 2010.

Yıldırım A. \& Şimşek H. (2008). Nitel Araştırma Yöntemleri. Ankara 2008. 